\title{
Determination of The Best Employees using Simple Additive Weighting (SAW) Method
}

\author{
Titin Prihatin ${ }^{1}$ \\ STMIK Nusa Mandiri: Teknik Informatika \\ Jakarta, Indonesia \\ titin.tpn@nusamandiri.ac.id
}

\author{
Tri Retnasari ${ }^{2}$ \\ STMIK Nusa Mandiri: Teknik Informatika \\ Jakarta, Indonesia \\ tri.trs@nusamandiri.ac.id
}

\author{
Muhammad Fikri ${ }^{3}$ \\ STMIK Nusa Mandiri: Teknik Informatika \\ Jakarta, Indonesia \\ fikrimr11@gmail.com
}

\begin{abstract}
One of the most important things in company management to improve employee performance is to make the best selection of employees on a regular basis so as to produce an attitude of service to the company. However, the mistakes in the determination process in the management of human resources (HR) of each company greatly affects several aspects, especially the success of the company's work itself. Therefore, this research tries to help PT. Buana Estate Agrowisata Villa Bukit Hambalang in choosing its best employees using the Simple Additive Weighting (SAW) Method. The Simple Additive Weighting (SAW) method is one of the methods in decision making where several alternatives are known and predetermined. To facilitate decision making in evaluating employees must determine priorities, weights, or rankings based on the criteria given. determined criteria include attendance, performance, discipline, attitude and neatness. Samples are employees who work at PT. Buana Estate Bukit Hambalang Villa Agrotourism. This study got the results of the number of employees as many as 25 employees who were used as research samples, the employee named Pathurochman got the biggest score of 0.95 and got the title of the best employee at PT. Buana Estate Agrowisata Villa Bukit Hambalang.
\end{abstract}

Keywords - Employee; Simple Additive Weighting.

\section{INTRODUCTION (HEADING 1)}

Human Resources (HR) in a company has a very important role continuity of the company so salary is mandatory given by the company to its employees, besides the usual salary the company gives awards in the form of bonuses to its employees, this is to motivate its employees in order to work harder again (Murdianto, Khairina, \& Hatta, 2016). The HR management of a company is very influence the determinants of success work and target achievement of the company. Therefore if HR can be organized well, it is hoped that the company can run all business processes well (Masri, 2016).

PT. Buana Estate Agrowisata Villa Bukit Hambalang was founded in 2012. PT. Buana Estate Agrowisata Villa Bukit Hambalang conducts the selection of the best employees to stimulate employee morale in increasing their dedication and performance. As a form of appreciation for employees who have done a good job. The appreciation is also expected to increase employee morale at work. Employee performance is quite influential in the profits derived by a company. Too many employees there are at the company makes these judgments sometimes quite difficult to do and results deemed inappropriate makes a problem that is in the determination of employees best. Companies sometimes have a hard time making decisions, especially if several existing employees have capabilities that are not much different into a problem in the determination of the best employees (Fitriah \& Irfiani, 2018). The process of evaluating employee performance at PT. Buana Estate Agrowisata Villa Bukit Hambalang is still in the 
form of hardcopy and decisions from one party so that the process is still not accurate and has problems in determining the best employees who are subjective. The subjectivity referred to arises if the employee is given an award due to a criterion without looking at other evaluation criteria. This subjectivity usually occurs to reduce the complexity of the decision-making process due to the many alternatives and more on the application put forward the feeling between likes and dislikes.

Unfair decision making can have a negative impact on a company. This can reduce the level of performance of employees at the company. There are several studies that have used the Simple Additive Weighting (SAW) method, such as to conduct performance index assessments conducted by (Muslihudin, et al, 2017), a decision support system can carry out the process of calculating employee performance appraisal so that it occurs to realize an appraisal that fair based on the calculation of existing criteria in the system using weighted product weights (WP) carried out by (Aminudin, et al, 2018). Finding the value weights for each attribute is then ranked which will determine the optimal alternative done by (Sahir, Rosmawati, \& Minan, 2017).

\section{LITERATURE REVIEW}

Research conducted by (Frieyadie, 2016), concludes from the results of analysis of calculations using the Simple Additive Weighting method and from the results of employee appraisal questionnaires consisting of work tenure criteria, performance appraisal and behavioral assessment, an employee named Chairani Syifa gets a perfect score with a percentage of $100 \%$ With details of the assessment of tenure for 4 years get a weighting value of 0.6 , a performance assessment of 5.30 gets a weighting of 0.8 and a behavior rating of 4.92 getting a weighting value of 0.8 . According to (Ismanto \& Effendi, 2017), employee performance appraisal in the Simple Additive Weighting (SAW) method there are criteria needed to determine who will be selected as new employees, including: Education, work experience, appearance, tests, interviews, age, status and address. According to (Septiani, 2017), in evaluating employee performance, accurate data processing is needed. There are 5 occupational fields in PLTD/G Tarahan, and in those occupations there are 3 variable criteria for evaluating employee performance in PLTD/G Tarahan obtained from the results of interviews, namely Absenteeism, Work Realization, Character.
Simple Additive weighting often also known as a weighted summation method. The basic concepts of the Simple Additive weighting is looking for a weighted summation of the rating performance of each alternative on all attributes. Simple Additive weighting method requires a process of normalizing the decision matrix $(\mathrm{X})$ to a certain scale that can be compared with all existing alternative rating. The steps to resolve a problem using Simple Additive weighting method, namely:

1. Specify the criteria that will be used taking decisions that $\mathrm{C}_{\mathrm{i}}$,

2. Leave a rating value match each alternate each alternative.

3. Make decisions based on the matrix criteria $\left(\mathrm{C}_{\mathrm{i}}\right)$, Then do normalization matrix based on the equation adjusted for the type of attributes (attributes advantage or attribute costs) so obtained normalized matrix R.

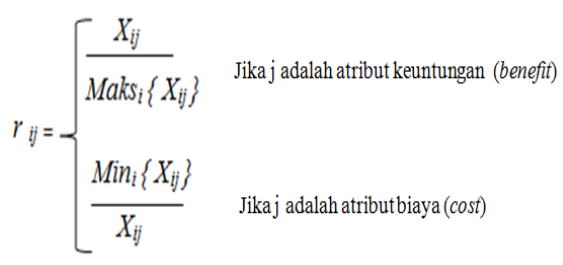

Information:

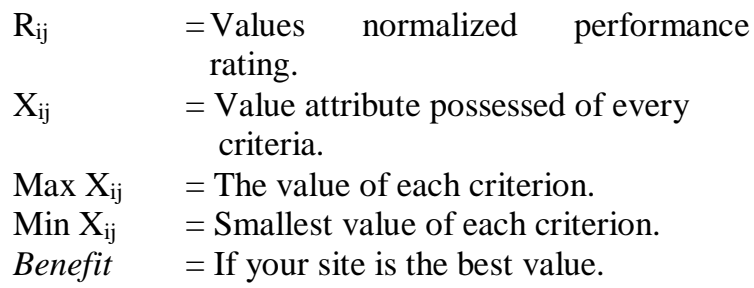

4. The final result is obtained from the process perangkingan that sum and $\mathrm{R}$ normalized matrix multiplication with a weight vector in order to obtain the greatest value Selected as a good alternative $\left(\mathrm{A}_{\mathrm{i}}\right)$ as a solution.

$$
\mathrm{V}_{\mathrm{i}}=\sum_{\mathrm{j}=1}^{\mathrm{n}} \mathrm{w}_{\mathrm{j}} \mathbf{r}_{\mathrm{ij}}
$$

Information:

$\mathrm{V}_{\mathrm{i}} \quad$ = Ranking for each alternative.

$\mathrm{W}_{\mathrm{j}} \quad=$ Value of the weight of each criterion.

$\mathrm{r}_{\mathrm{ij}} \quad=$ Value normalized performance rating. 


\section{Proposed Method}

Our research stages are divided into four stages, including:

1. Pre-Field Stage

The first week the author requested permission orally from the HRD \& GA Manager to request research permission at PT. Buana Estate Agrowisata Villa Bukit Hambalang.

2. Stage of Field Work

The fieldwork stage is carried out according to the schedule given by the company. This stage the author asks several questions to the HRD \& GA Manager relating to the best employees and what are the criteria that must be met in order to be rated as the best employee. Then the questionnaire was given to each Section Chief to fill out the questionnaire.

3. Data Analysis Stage

In this third stage, the authors conducted a series of analysis processes and arrived at the interpretation of employee data that had been obtained previously. Here the author also requests data needed through analysis. Questionnaires that have been filled in are graded according to the provisions that will be obtained with the formula of the method to be used until the results are found.

4. Evaluation and Reporting Phase

At this stage the authors re-examine the questionnaire analysis process that has been done previously, to minimize errors that might appear when making reports and conduct final research.

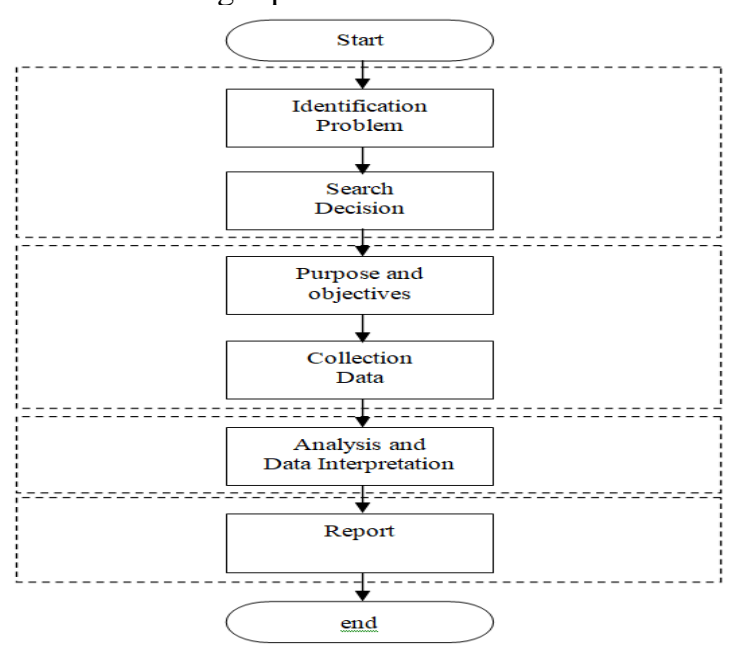

Fig.1 Research Steps

\section{RESUlt AND DiscusSion}

In determining the best employees at PT. Buana Estate Agro Villa Bukit Hambalang, party companies to collect data on employees in the determination of the best employees with the criteria specified. One of the best employees of the completion of the determination of PT. Buana Estate Agrowisata Villa Bukit Hambalang, the necessary criteria and weighting in the calculation so as to obtain the best alternative results using Simple Additive weighting method (SAW) as follows.

1. Determining each each criterion.

TABLE 1. CRITERIA PROVISIONS

\begin{tabular}{lc}
\hline Code & Criteria \\
\hline $\mathrm{C} 1$ & Attendance \\
$\mathrm{C} 2$ & performance \\
$\mathrm{C} 3$ & Discipline \\
$\mathrm{C} 4$ & Attitude \\
$\mathrm{C} 5$ & Neatness \\
\hline
\end{tabular}

2. Furthermore give weight to each criterion.

TABLE 2. DETERMINATION OF VALUE

\begin{tabular}{lll}
\hline Appraisal & Information & Value \\
\hline $\mathbf{1 - 2 0}$ & Very low & $\mathbf{1}$ \\
$\mathbf{2 1 - 4 0}$ & Low & $\mathbf{2}$ \\
$\mathbf{4 1 - 6 0}$ & moderate & $\mathbf{3}$ \\
$\mathbf{6 1 - 8 0}$ & High & 4 \\
$\mathbf{8 1 - 1 0 0}$ & Very high & 5 \\
\hline
\end{tabular}

The weighting criteria by the author in the study determining the best employees, as follows.

a. Attendance Assessment Criteria

TABle 3. Assessment AtTEndance

\begin{tabular}{lll}
\hline Attendance Rate & Information & Value \\
\hline $1 \%-20 \%$ & Very low & 1 \\
$21 \%-40 \%$ & Low & 2 \\
$41 \%-60 \%$ & moderate & 3 \\
$61 \%-80 \%$ & High & 4 \\
$81 \%-100 \%$ & Very high & 5 \\
\hline
\end{tabular}


b. Performance Assessment Criteria

TABle 4. Performance Assessment

\begin{tabular}{lll}
\hline $\begin{array}{l}\text { Performance } \\
\text { Assessment }\end{array}$ & Information & Value \\
\hline $1-20$ & Very low & 1 \\
$21-40$ & Low & 2 \\
$41-60$ & moderate & 3 \\
$61-80$ & High & 4 \\
$81-100$ & Very high & 5 \\
\hline
\end{tabular}

c. Discipline Assessment Criteria

TABLE 5. ASSESSMENT DisciPlinE

\begin{tabular}{lll}
\hline Rate Discipline & Information & Value \\
\hline $\mathbf{1 - 2 0}$ & Very low & $\mathbf{1}$ \\
$\mathbf{2 1 - 4 0}$ & Low & $\mathbf{2}$ \\
$\mathbf{4 1 - 6 0}$ & moderate & $\mathbf{3}$ \\
$\mathbf{6 1 - 8 0}$ & High & $\mathbf{4}$ \\
$\mathbf{8 1 - 1 0 0}$ & Very high & $\mathbf{5}$ \\
\hline
\end{tabular}

d. Attitudes Assessment Criteria

TABLE 6. Assessment AtTITUdE

\begin{tabular}{lll}
\hline Attitude Assessment & Information & Value \\
\hline $1-20$ & Very low & 1 \\
$21-40$ & Low & 2 \\
$41-60$ & moderate & 3 \\
$61-80$ & High & 4 \\
$81-100$ & Very high & 5 \\
\hline
\end{tabular}

e. Assessment criteria Neatness

TABLE 7. ASSESSMENT KERAPIHAN

\begin{tabular}{lll}
\hline Neatness Assessment & Information & Value \\
\hline $1-20$ & Very low & 1 \\
$21-40$ & Low & 2 \\
$41-60$ & moderate & 3 \\
$61-80$ & High & 4 \\
$81-100$ & Very high & 5 \\
\hline
\end{tabular}

3. Determining the Value Rating suitability of each employee on each criterion.

TABLE 8. RATING MATCHES

\begin{tabular}{llllll}
\hline Employee name & \multicolumn{5}{c}{ Assessment criteria } \\
or Alternative & C1 & C2 & C3 & C4 & C5 \\
\hline Seftian Dwi S. & 5 & 5 & 5 & 4 & 2 \\
Aceh Yusnidar & 5 & 5 & 5 & 3 & 1
\end{tabular}

\begin{tabular}{llllll}
\hline Employee name & \multicolumn{6}{l}{ Assessment criteria } \\
or Alternative & C1 & C2 & C3 & C4 & C5 \\
\hline Ade Priyatna & 4 & 4 & 3 & 3 & 1 \\
Rio adventus & 4 & 4 & 4 & 4 & 1 \\
Fredy Fuja & 4 & 4 & 3 & 3 & 1 \\
HM Fikri & 4 & 4 & 4 & 4 & 1 \\
Dani Ariah & 4 & 4 & 4 & 3 & 2 \\
Saepul & 4 & 4 & 4 & 4 & 2 \\
Didier Saprudin & 4 & 4 & 3 & 3 & 1 \\
Agus Riyanto & 5 & 5 & 5 & 4 & 4 \\
Agus Widodo & 5 & 5 & 4 & 4 & 1 \\
Pathurochman & 4 & 5 & 3 & 3 & 2 \\
Ning Tyas & 4 & 5 & 5 & 5 & 2 \\
Endrowinarsih & 4 & 4 & 3 & 3 & 1 \\
Endah & 4 & 5 & 5 & 5 & 2 \\
Charlye & 4 & 4 & 5 & 5 & 4 \\
Muji Lestari & 5 & 5 & 5 & 5 & 5 \\
Supangat & 5 & 4 & 4 & 4 & 3 \\
Encep Supriyadi & 4 & 5 & 4 & 4 & 4 \\
Suhendri & 5 & 4 & 5 & 4 & 4 \\
Memed & 4 & 5 & 3 & 3 & 3 \\
Suhendi & 4 & 4 & 4 & 5 & 3 \\
Atang Hidayat & 4 & 4 & 5 & 3 & 1 \\
Khoerudin & 4 & 5 & 4 & 4 & 3 \\
Aceng Kurnia & 4 & 5 & 4 & 4 & 5 \\
\hline & & & & &
\end{tabular}

4. Make the Decision Matrix was formed from the following Table Match Rating

$\mathbf{X}=\left[\begin{array}{lllll}5 & 5 & 5 & 4 & 2 \\ 5 & 5 & 5 & 3 & 1 \\ 4 & 4 & 3 & 3 & 1 \\ 4 & 4 & 4 & 4 & 1 \\ 4 & 4 & 3 & 3 & 1 \\ 4 & 4 & 4 & 4 & 1 \\ 4 & 4 & 4 & 3 & 2 \\ 4 & 4 & 4 & 4 & 2 \\ 4 & 4 & 3 & 3 & 1 \\ 5 & 5 & 5 & 5 & 4 \\ 5 & 5 & 4 & 4 & 1 \\ 4 & 5 & 3 & 3 & 2 \\ 4 & 5 & 5 & 5 & 2 \\ 4 & 4 & 3 & 3 & 1 \\ 4 & 5 & 5 & 5 & 2 \\ 4 & 4 & 5 & 5 & 4 \\ 5 & 5 & 5 & 5 & 5 \\ 5 & 4 & 4 & 5 & 3 \\ 4 & 5 & 4 & 4 & 4 \\ 5 & 4 & 5 & 4 & 4 \\ 4 & 5 & 3 & 3 & 3 \\ 4 & 4 & 4 & 5 & 3 \\ 4 & 4 & 5 & 3 & 1 \\ 4 & 5 & 4 & 4 & 3 \\ 4 & 5 & 4 & 4 & 5\end{array}\right]$


Then the result of the normalization of the above made in the normalized matrix $(\mathrm{R})$ as follows:

\begin{tabular}{|c|c|c|c|c|}
\hline-1 & 1 & 0.6 & 0,75 & 0,5 \\
\hline 1 & 1 & 06 & 1 & 1 \\
\hline 0.8 & 0,8 & 1 & 1 & 1 \\
\hline 08 & 0,8 & 0,75 & 0,75 & 1 \\
\hline 08 & 0,8 & 1 & 1 & 1 \\
\hline 0.8 & 0,8 & 0,75 & 0,75 & 1 \\
\hline 0.8 & 0,8 & 0,75 & 1 & 0,5 \\
\hline 08 & 0,8 & 0,75 & 0,75 & 0,5 \\
\hline 0.8 & 0,8 & 1 & 1 & 1 \\
\hline 1 & 1 & 0.6 & 0,75 & 0,25 \\
\hline 1 & 1 & 0,75 & 0,75 & 1 \\
\hline 0.8 & 1 & 1 & 1 & 0,5 \\
\hline 0.8 & 1 & 0,6 & 0,6 & 0,5 \\
\hline 0.8 & 0,8 & 1 & 1 & 1 \\
\hline 08 & 1 & 0,6 & 0,6 & 0,5 \\
\hline 08 & 0,8 & 0,6 & 0,6 & 0,25 \\
\hline 1 & 1 & 0.6 & 0,6 & 0,2 \\
\hline 1 & 0.8 & 0,75 & 0,75 & 0,33 \\
\hline 0,8 & 1 & 0,75 & 0,75 & 0,25 \\
\hline 1 & 0.8 & 0,6 & 0,75 & 0,25 \\
\hline 0,8 & 1 & 1 & 1 & 0,33 \\
\hline 0,8 & 0,8 & 0,75 & 0,6 & 0,33 \\
\hline 0.8 & 0,8 & 0,6 & 1 & 1 \\
\hline 0.8 & 1 & 0,75 & 0,75 & 0,33 \\
\hline 08 & 1 & 0,75 & 0,75 & 0,2 \\
\hline
\end{tabular}

5. The final step is the process of ranking the best value by entering or each criteria and the weights used in the The value calculations for each employee with a value of $\mathrm{V}$, can be seen in the following table:

TABLE 9. RESULTS ON RANKING

\begin{tabular}{lll}
\hline Employee name & Employee & V \\
\hline Seftian Dwi S. & A1 & .832 \\
Aceh Yusnidar & A2 & 0.92 \\
Ade Priyatna & A3 & .852 \\
Rio adventus F. S & A4 & .852 \\
Fredy Fuja & A5 & 0.69 \\
HM Fikri & A6 & 0.802
\end{tabular}

\begin{tabular}{lll}
\hline Employee name & Employee & V \\
Ariah Dani S. & A7 & 0.79 \\
Saepul & A8 & 0.752 \\
Didier Saprudin & A9 & 0.89 \\
Agus Riyanto & A10 & .807 \\
Agus Widodo & A11 & 0.192 \\
Pathurochman & A12 & 0.89 \\
Ning Tyas & A13 & 0.75 \\
Endrowinarsih & A14 & 0.89 \\
Endah & A15 & 0.75 \\
Charlye & A16 & 0.7 \\
Muji Lestari & A17 & 0.78 \\
Supangat & A18 & 0,795 \\
Encep Supriyadi & A19 & .777 \\
Suhendri & A20 & .757 \\
Memed & A21 & .873 \\
Suhendi & A22 & .713 \\
Atang Hidayat & A23 & 0.81 \\
Khoerudin & A24 & 0.785 \\
Aceng Kurnia & A25 & 0.722 \\
\hline
\end{tabular}

Furthermore, employees are sorted from largest to the value $\mathrm{V} \mathrm{V}$ smallest value, employees with the largest value of $\mathrm{V}$ is the best result. And sorting the results table as follows:

TABLE 10. RESULTS ORDERING

\begin{tabular}{llll}
\hline No. & Employee name & Employee & Value \\
\hline 1 & Aceh Yusnidar & A2 & 0.92 \\
2 & Pathurochman & A12 & 0.89 \\
3 & Endrowinarsih & A14 & 0.89 \\
4 & Didier Saprudin & A9 & 0.89 \\
5 & Memed & A21 & .873 \\
6 & Rio adventus F. S & A4 & .852 \\
7 & Ade Priyatna & A3 & .852 \\
8 & Seftian Dwi S. & A1 & .832 \\
9 & Atang Hidayat & A23 & 0.81 \\
10 & Agus Riyanto & A10 & .807 \\
11 & HM Fikri & A6 & 0.802 \\
12 & Supangat & A18 & 0,795 \\
13 & Ariah Dani S. & A7 & 0.79 \\
14 & Khoerudin & A24 & 0.785 \\
15 & Muji Lestari & A17 & 0.78 \\
16 & Encep Supriyadi & A19 & .777 \\
17 & Suhendri & A20 & .757 \\
\hline
\end{tabular}




\begin{tabular}{llll}
\hline 18 & Saepul & A8 & 0.752 \\
19 & Ning Tyas & A13 & 0.75 \\
20 & Endah & A15 & 0.75 \\
21 & Aceng Kurnia & A25 & 0.722 \\
22 & Suhendi & A22 & .713 \\
23 & Charlye & A16 & 0.7 \\
24 & Fredy Fuja & A5 & 0.69 \\
25 & Agus Widodo & A11 & 0.192 \\
\hline
\end{tabular}

So from the above calculation, the employee on behalf of the Aceh Yusnidar the best employees with the highest score (0.92).

\section{CONClusionand Suggestion}

In accordance with the results of the research Determining the Best Employee At PT. Buana Estate Agrowisata Villa Bukit Hambalang Using Simple Additive weighting method (SAW), the authors draw the following conclusion:

1. Of the process and the results of this study, the authors understand how the procedure is in fulfilling election -procedure best employees.

2. Process undertaken to determine the best employees through calculation with Simple Additive weighting method (SAW) started by giving criteria include the value of Attendance, Performance, Discipline, Attitude and neatness. Resulting in the value of each criterion.

3. With the implementation of Simple Additive weighting method (SAW), producing a good decision in the settlement and calculation criteria values that employees, in order to know accurate results in the process of selecting the best employees.

4. The process of selecting the best employees at PT. Buana Estate Agrowisata Villa Bukit Hambalang Using Simple Additive weighting method (SAW), was given to Mrs. Aceh Yusnidar conducted through the calculation starts with the grading criteria, weighting, rating the suitability, normalization and ranking resulting value of each criterion.

\section{ACKNOWLEDGMENT}

Gratitude to Allah Subhanahu wata'ala for all the blessings and knowledge given to us, and we would like to use this opportunity to thank the management of PT. Buana Estate Agrowisata Villa Bukit Hambalang for the opportunity that has been given to us, and we want to thank our research group, who gave us a lot of insights and ideas so that this research can be completed. Also, thank you very much to the SinkrOn Polytechnic Ganesha Journal team, Medan.

\section{REFERENCES}

Aminudin, Nur, et al. (2018). Weighted Product and Its Application to Measure Employee Performance. International Journal of Engineering \& Technology (www.sciencepubco.com/index.php/IJET), 7 (2.26), 102-108.

Fitriah, A., \& Irfiani, E. (2018). Sistem Pendukung Keputusan Pemilihan Pegawai Terbaik PT Pegadaian Jakarta Dengan Metode Simple Additive Weighting. Information System for Educators and Professionals, 2(2), 105-114. Retrieved from http://ejournalbinainsani.ac.id/index.php/ISBI/article/view/7 47.

Frieyadie. (2016). Penerapan Metode Simpe Additive Weighting (SAW) Dalam Sistem Pendukung Keputusan Promosi Kenaikan Jabatan. Jurnal Pilar Nusa Mandiri, 12(1), $37-45$.

Ismanto, E., and Effendi, N. (2017). Sistem Pendukung Keputusan Penerimaan Karyawan Dengan Metode Simple Additive Weighting (SAW). SATIN-Sains dan Teknol. Inf., 03( 01), $1-9$.

Masri, M. (2016). Penentuan Karyawan Terbaik Dengan Metode Simple Additive Weighting (PDAM Tirta Silaupiasa). Journal of Electrical Technology, 1(1), 36-41.

Murdianto, H., Khairina, D. M., \& Hatta, H. R. (2016). Sistem Pendukung Keputusan Pemilihan Karyawan Terbaik Per Triwulan Pt.Cahaya Fajar Kaltim Pltu Embalut Tanjung Batu Menggunakan Metode Simple Additive Weighting. Prosiding Seminar Ilmu Komputer Dan Teknologi Informasi , 1(1), 24-29. https://doi.org/10.17605/OSF.IO/J4YVA

Muslihudin, M., Triananingsih, kasmi, F., \& Anggraei, L. (2017). Pembuatan Model Penilaian Indeks Kinerja Dosen Menggunakan Metode Fuzzy Simple Additive Weighting. Prosiding Seminar Nasional Teknologi Informasi dan Multimedia 2017. no. 25-30, ISSN. 2302-3805, STMIK AMIKOM Yogyakarta.

Sahir, Syafrida Hafni., Rosmawati, R., \& Minan, 
Kresna. (2017). Simple Additive Weighting Method to Determining Employee Salary Increase Rate. International Journal of Scientific Research in Science and Technology (www.ijsrst.com), 3(8), ISSN. 2395-602X, 4248.
Septiani, U. (2017). Sistem Informasi Penilaian Kinerja Karyawan Dengan Metode Simple Additive Weighting (Saw) Dan 360 Derajat Pada PLTD/G Tarahan Bandar Lampung. Jurnal Komputasi, 5(2), 64-73. 